\title{
Rencana Kebijakan dan Program Pembangunan Hortikultura Lahan Kering untuk Provinsi Sumatera Utara: Sudah Tepatkah?
}

\section{Dany Juhandia, Ardian Elonard Purba ${ }^{a}$}

aPoliteknik Wilmar Bisnis Indonesia, Deli Serdang - SUMUT, Indonesia

Corresponding author: dany.juhandi@wbi.ac.id

\section{Article Info}

Article history:

Received 17 March 2021

Received in revised from 27 March 2021

Accepted 02 June 2021

DOI:

https://doi.org/10.32938/ag.v6i3.1341

Keywords:

Horticulture

Policy

Dryland

\begin{abstract}
Abstrak
Consumption of fruits and vegetables increases the demand of horticultural commodities but increasing of horticultural production is smaller than increasing of its demand so that imports are necessary to fill in these consumption needs. The government in 2019 plans horticultural commodities to every province in Indonesia. The objectives of this study were (1) to analyze superior horticultural commodities in North Sumatra Province, (2) to analyze the specialist and localization of horticultural commodities in North Sumatra, and (3) to compare priority horticultural commodities from the analysis results with government policy plans. Secondary data used in this study were from 2017 - 2019. The analytical tools used were Location Quotient (LQ), Specialization Quotient (SQ) and Localization Quotient (LoQ). The results showed (1) superior dryland horticultural comodities were dominated by shallots, chilies, mangoes, durian, papaya and galangal in North Tapanuli, Toba Samosir and Dairi Regencies, (2) several dryland horticultural commodities has a comparative advantage and its production is not localized, such as mango, durian, and chili in Batubara and Labuhan Batu Selatan Regencies, and (3) fifty percent of dry land horticultural commodities were priority commodities.
\end{abstract}

\section{Pendahuluan}

Komoditas hortikultura yang meliputi tanaman buah-buahan, sayur-sayuran, bunga dan tanaman obat diduga tidak menjadi perhatian utama pemerintah. Berdasarkan data BPS tahun 2018 menunjukkan bahwa kesadaran masyarakat mengonsumsi buah dan sayuran terus meningkat. Pada tahun 2012 konsumsi rata-rata perkapita untuk sayur-sayuran sebesar 37,90 Kkal kemudian mengalami peningkatan pada tahun 2018 menjadi 39,89 Kkal. Di sisi lain konsumsi rata-rata perkapita buah-buahan pada tahun 2012 sebesar 35,38 Kkal menjadi 45,31 Kkal pada tahun 2018 (BPS, 2018).

Produksi komoditas hortikultura tahun 2013 - 2017 mengalami peningkatan. Produksi tanaman sayuran dari 11.558.449 ton meningkat menjadi 12.481 .893 ton, tanaman buah-buahan 18.288.279 ton menjadi 19.643.616 ton, tanaman florikultura 684.097.623 ton menjadi 819.324.716 ton, dan tanaman biofarmaka 453.206.124 ton menjadi 488.538.761 ton (Kementan, 2018). Sekalipun produksi komoditas hortikultura meningkat, tetapi pertumbuhan produksinya tidak lebih dari pertumbuhan konsumsi komoditas hortikultura, sehingga untuk memenuhi permintaan tersebut pemerintah melakukan impor komoditas hortikultura.

Pada tahun 2007 nilai impor komoditas hortikultura sebesar US\$810,1 juta, meningkat menjadi US\$847,7 juta pada tahun 2013, sehingga neraca perdagangan komoditas hortikultura defisit sekitar US\$345,6 juta - US\$555,6 juta pada tahun tersebut (Nuhung, 2013). Berdasarkan data Kemendang (Kementerian Perdagangan) tahun 2019 bahwa nilai impor komoditas buahbuahan pada tahun 2014 hanya US\$789,2 juta menjadi US\$1.310,9 juta pada tahun 2018. Namun, nilai impor komoditas sayuran sebesar US\$644 juta menjadi US\$783,4 juta pada tahun 2018 (Kemendag, 2019). Menurut Santosa et al (2018) beberapa komoditas hortikultura memiliki daya saing di pasar global. Komoditas hortikultura ini mendapatkan perhatian dan dikembangkan akan menjadi komoditas potensial untuk menambah nilai neraca perdagangan Indonesia.

Permasalahan dan peluang yang harus dihadapi di era perdagangan bebas saat ini dalam upaya pengembangan komoditas hortikultura antara lain (1) biaya input produksi yang relatif tinggi, (2) komoditas hortikultura diusahakan petani bukan untuk konsumsi sendiri sehingga petani harus memiliki skill membaca peluang pasar, dan (3) Permintaan komoditas hortikultura yang dinamis karena komoditas yang beragam (Irawan, 2003). Peluang dan tantang dalam pengembangan komoditas hortikultura, pemerintah perlu menyiapkan strategi yang tepat. Strategi pengembangan usaha hortikultura melalui kebijakan bisa seperti subsidi sarana produksi, perbaikan harga produksi, dan pemberian kredit kepada petani (Antara, 2005).

Pemerintah saat ini memiliki rencana kebijakan dan program pembangunan hortikultura 2020 yang memiliki strategi khusus untuk meningkatkan produksi komoditas hortikultura lahan kering tertentu melalui spesifik wilayah (Hortikultura, 2020). Setiap provinsi memiliki komoditas yang direncanakan untuk ditingkatkan produksinya. Provinsi Sumatera Utara dalam perencanaan pembangunan hortikultura 2020 direncanakan untuk meningkatkan beberapa komoditas 
hortikultura lahan kering, seperti sayuran (aneka cabai, bawang merah, bawang putih, sayuran daun dan kentang), buah-buahan (jeruk, pisang, dan lengkeng), florikultura (krisan dan anggrek) sedangkan untuk tanaman obat belum dijelaskan secara spesifik tanaman apa yang akan dikembangkan (Hortikultura, 2020). Adanya rencana pembangunan wilayah yang berfokus pada pengembangan komoditas yang spesifik sebenarnya berdasarkan model keuntungan komparatif (comparative advantage model). Dengan menggunakan model keuntungan komparatif model yang terspesialisasi memungkinkan suatu wilayah untuk menjual hasil produksinya ke wilayah lain karena harga komoditas di wilayah lain lebih tinggi, sehingga ini menguntungkan bagi daerah yang memiliki keunggulan komparatif. Keunggulan komparatif suatu wilayah bisa ditentukan oleh beberapa alat analisis yang biasa digunakan dalam analisis ekonomi wilayah (Sjafrizal, 2008).

Berdasarkan fakta dan permasalahan dijabarkan tersebut, maka tujuan penelitian ini yaitu (1) menganalisis komoditas hortikultura unggulan lahan kering di Provinsi Sumatera Utara, (2) menganalisis spesialisasi dan lokalisasi komoditas hortikultura lahan kering di Sumatera Utara, dan (3) membandingkan komoditas hortikultura prioritas lahan kering dari hasil analisis dengan rencana kebijakan pemerintah.

\section{Metode}

\subsection{Metode Dasar Penelitian}

Penelitian eksplorasi ini menggunakan metode deskriptif kuantitatif yang karakteristik populasi atau bidang tertentu dideskrispsikan secara sistematis dan aktual. Variabel-variabel penelitian dalam penelitian ini yaitu jumlah produksi, harga komoditas, dan nilai produksi komoditas hortikultura lahan kering. Data jumlah produksi dan harga komoditas digunakan untuk mencari nilai produksi komoditas yang merupakan hasil kali jumlah produksi dengan harga.

\subsection{Daerah Penelitian}

Penelitian ini menganalisis rencana kebijakan dan program pembangunan hortikultura lahan kering di semua kabupaten/kota yang ada di Provinsi Sumatera Utara. Provinsi Sumatera Utara merupakan salah satu provinsi di Pulau Sumatera yang memiliki jumlah kabupaten/kota terbanyak. Di Provinsi Sumatera Utara terdapat 25 Kabupaten dan 8 Kota Madya yang masingmasing memiliki karakteristik geografis dan lahan yang berbeda-beda.

\subsection{Pengumpulan Data}

Data sekunder yang digunakan dalam penelitian ini diperoleh dari Badan Pusat Statistik (BPS) dan Kementerian Pertanian. Data yang dikumpulkan meliputi data komoditas hortikultura seperti tanaman cabai, bawang, buah-buahan dan tanaman bunga yang khusus dibudidayakan di lahan kering. Data yang digunakan data time series untuk setiap komoditas hortikultura lahan kering mulai data tahun $2017-2019$.

\subsection{Teknik Analisis Data}

\subsubsection{Mengidentifikasi Komoditas Hortikultura Unggulan Lahan Kering di Provinsi Sumatera Utara}

Komoditas hortikultura prioritas diidentifikasi dengan menggunakan tiga kombinasi alat analisis yaitu Location Quotient (LQ), Specialization Quotient (SQ) and Localization Quotient (LoQ) Propis dalam Crawley et al.,(2013) merumuskan LQ sebagai berikut:

$$
L Q=\frac{x_{i} / n_{i}}{x / n} .
$$

xi merupakan jumlah nilai produksi komoditas hortikultura di tingkat kabupaten/kota, ni adalah jumlah total nilai produksi komoditas hortikultura di tingkat kabupaten/kota i. $\mathrm{x}$ adalah jumlah nilai produksi komoditas hortikultura di tingkat provinsi, dan $\mathrm{n}$ adalah jumlah total nilai produksi komoditas hortikultura di tingkat provinsi. Kriteria hasil alat analisis ini jika nilai LQ $>1$ maka komoditas i dikategorikan sebagai komoditas unggulan yang produksinya pada komoditas $\mathrm{i}$ lebih besar dibandingkan daerah di atasnya. $\mathrm{LQ}=1$ maka komoditas i dikategorikan seimbang yang produksi komoditas i seimbang dengan daerah atas, kemudian jika LQ $<1$ maka komoditas $\mathrm{i}$ dikategorikan sebagai komoditas bukan unggulan karena pangsa produksi pada komoditas i lebih kecil dibandingkan daerah atas (Fimbriata et al, 2020).

\subsubsection{Menganalisis Spesialisasi dan Lokalisasi Komoditas Hortikultura Lahan Kering di Provinsi Sumatera Utara}

Specialization Quotient (SQ) dan Localization Quotient (LoQ) digunakan untuk menentukan distribusi dan pemusatan produksi komoditas hortikultura lahan kering. Spesialisasi terhadap suatu kegiatan pertanian di suatu wilayah kabupaten/kota dan spesialisasi terhadap komoditas hortikultura tertentu di tingkat Provinsi Sumatera Utara yang digunakan analisis SQ. Kriterianya 
jika SQ $\geq 1$ berarti di tingkat kabupaten/kota terdapat spesialisasi terhadap kegiatan pertanian untuk komoditas hortikultura terspesialisasi pada suatu kabupaten, dan jika SQ $\leq$ Oberarti komoditas hortikultura tidak terspesialisasi di beberapa wilayah di kabupaten. Di tingkat kabupaten/kota tidak terdapat spesialisasi kegiatan pertanian tertentu jika nilai $\mathrm{SQ}<1$ dan mendekati nol. Tetapi kabupaten/kota sudah memiliki keunggulan komparatif dalam menghasilkan komoditas hortikultura tertentu jika nilai SQ positif. (Ropingi, 2006). Menurut Vaulina (2016) SQ mempunyai formulasi sebagai berikut:

$$
S Q=\left\{\left(\frac{S_{i}}{\sum S_{i}}\right)-\left(\frac{N_{i}}{\sum N_{i}}\right)\right\}
$$

Si merupakan nilai produksi komoditas hortikultura di tingkat provinsi, Ni adalah nilai produksi komoditas hortikultura di tingkat nasional, $\Sigma \mathrm{Si}$ adalah total nilai produksi komoditas hortikultura di tingkat provinsi dan $\Sigma \mathrm{Ni}$ adalah total nilai produksi pertanian di tingkat nasional. Localization Quotient (LoQ) digunakan untuk mengukur penyebaran (konsentrasi) relative/lokalisasi pengembangan komoditas di suatu wilayah. Vaulina \& Khairizal (2016) membuat formulasi LoQ yaitu

$$
L o Q=\left\{\left(\frac{s_{i}}{N_{i}}\right)-\left(\frac{\sum s_{i}}{\sum N_{i}}\right)\right\}
$$

Kriterianya jika LoQ $\geq 1$ berarti terjadi pemusatan terhadap kegiatan pertanian dan jika LoQ $\leq 0$ berarti tidak terjadi pemusatan terhadap kegiatan pertanian. Komoditas hortikultura lahan kering prioritas ditentukan dari nilai $\mathrm{LQ}>1$ dan $\mathrm{SQ} \geq 1$.

\subsubsection{Menganalisis Komoditas Hortikultura Prioritas Lahan Kering di Provinsi Sumatera Utara}

Kombinasi nilai LQ terbesar dan SQ tertinggi dari komoditas hortikultura lahan kering menunjukkan bahwa komoditas tersebut merupakan komoditas prioritas. Potensi keunggulan komoditas hortikultura lahan kering ditunjukkan dengan nilai LQ yang semakin besar. Keunggulan komparatif komoditas hortikultura lahan kering ditunjukkan dengan nilai SQ. Jadi nilai LQ terbesar dan SQ tertinggi yang dimiliki komoditas hortikultura lahan kering merupakan komoditas yang diprioritaskan untuk dikembangkan di wilayah kabupaten/kota tersebut.

Analisis perbandingkan komoditas hortikultura dilakukan dengan membandingkan komoditas hortikultura yang direncanakan untuk dikembangkan dan komoditas hortikultura hasil analisis pada penelitian ini. Berdasarkan Tabel 1. akan dibandingkan dengan hasil analisis komoditas hortikultura prioritas hasil analisis pada penelitian ini. Berikut adalah tabel komoditas hortikultura yang direncanakan untuk dikembangkan di Provinsi Sumatera Utara oleh Direktur Jenderal Hortikultura Kementerian Pertanian.

\section{Tabel 1.}

Rencana Komoditas Hortikultura Lahan Kering Provinsi Sumatera Utara Tahun 2020 oleh Dirjen Hortikultura.

\begin{tabular}{cl}
\hline No. Kelompok Tanaman & Komoditas \\
\hline 1. Sayur-sayuran & Aneka Cabai \\
& Bawang Merah \\
& Bawah Putih \\
& Sayuran Daun \\
& Kentang \\
2. Buah-buahan & Jeruk \\
& Pisang \\
3. Tanaman Obat & Lengkeng \\
4. Bunga & - \\
& Krisan \\
\hline
\end{tabular}

Sumber: Dirjen Hortikultura, 2019

Pada Tabel 2. terlihat hasil analisis LQ terhadap komoditas hortikultura lahan kering di Provinsi Sumatera Utara di mana sayuran yang menjadi komoditas unggulan paling sedikit yaitu kentang dan kubis. Komoditas ini hanya menjadi unggulan di 3 kabupaten saja yaitu Kabupaten Simalungun, Karo dan Samosir. Komoditas kentang menjadi komoditas unggulan lahan kering di 
Kabupaten Karo, sehingga diperlukan pengembangan untuk meningkatkan daya saing melalui peningkatan kualitas SDM atau petani, infastruktur dan pengembangan produk (Silvia et al, 2015).

\section{Hasil dan Pembahasan}

\subsection{Analisis Komoditas Hortikultura Unggulan Lahan Kering di Provinsi Sumatera Utara}

\subsubsection{Tanaman Sayuran}

Komoditas lain seperti bawang merah, cabai, petsai, tomat dan bawang putih menjadi komoditas unggulan di banyak daerah kabupaten/kota di Provinsi Sumatera Utara. Komoditaskomoditas ini hampir merata diproduksi banyak kabupaten/kota di Provinsi Sumatera Utara karena komoditas ini lebih prospektif dari sisi harga sehingga berpeluang untuk meningkatkan pendapatan petani yang bisa menjadi motivasi petani untuk berbudiya tanaman tersebut (Lestari et al., 2014). Komoditas cabai hampir di semua kabupaten/kota menjadi komoditas unggulan, sehingga bisa dikatakan sebagai komoditas unggulan Provinsi Sumatera Utara (Habib, 2019). Hal serupa juga ditemukan hasil penelitian Hendayana (2003) bahwa komoditas cabai memiliki nilai $\mathrm{LQ}=1,45$ untuk Provinsi Sumatera Utara yang dibandingkan dengan Provinsi lain yang ada di Indonesia.

\section{Tabel 2.}

Hasil Analisis LQ Tanaman Sayuran di Provinsi Sumatera Utara (Nilai LQ>1).

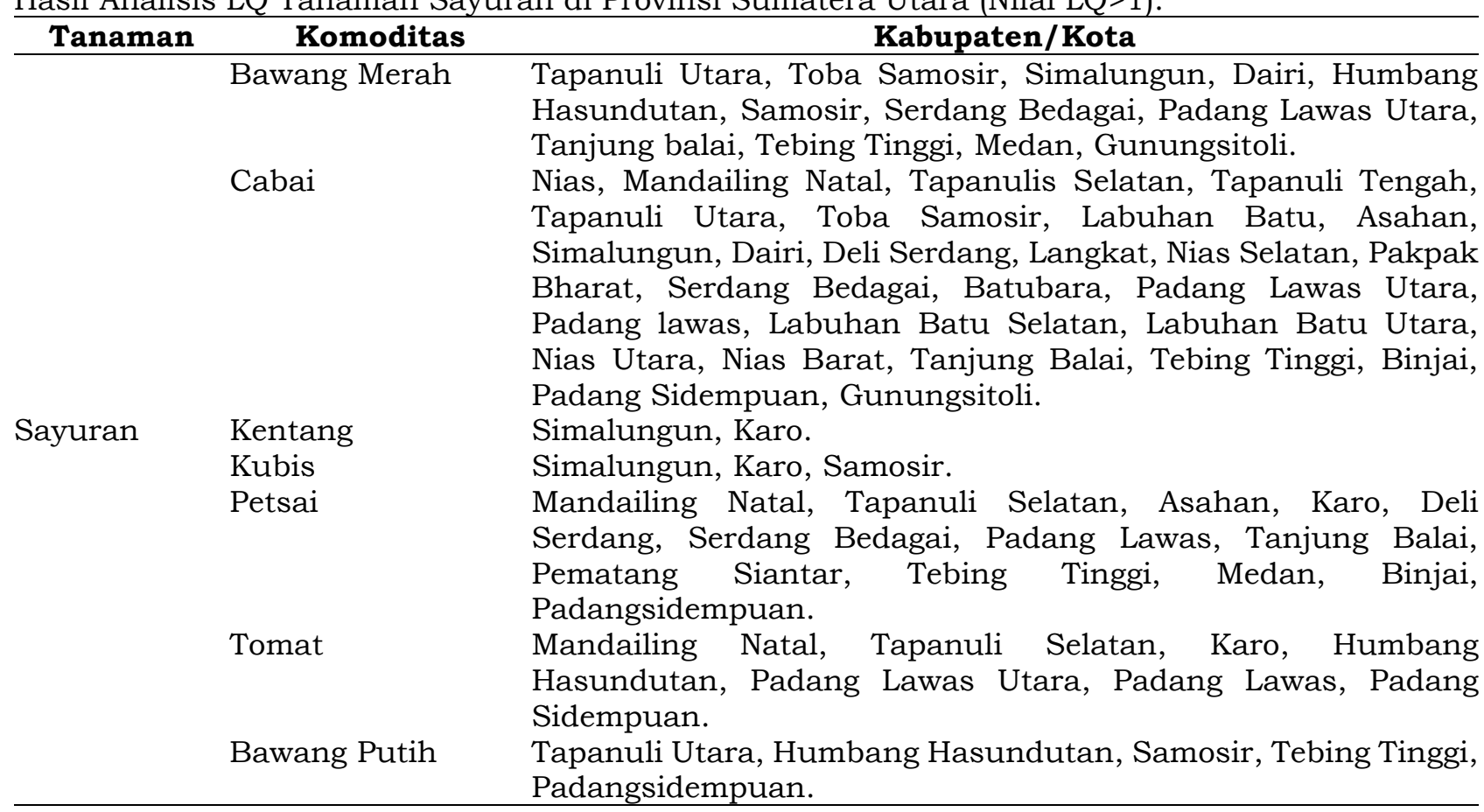

Sumber: Hasil Analisis LQ

\subsubsection{Tanaman Buah-Buahan}

Berdasarkan Tabel 3. tanaman buah-buahan lebih familiar jika dibandingkan dengan tanaman sayuran. Tanaman buah-buahan menjadi komoditas hortikultura unggulan lahan kering di banyak daerah kabuapaten/kota di Provinsi Sumatera Utara. Komoditas jeruk dan salak yang menjadi komoditas unggulan di beberapa daerah saja. Jeruk menjadi komoditas unggulan di Kabupaten Tapanuli Utara, Dairi, Karo dan Pakpak Bharat. Namun, salak menjadi komoditas unggulan di Kabupaten Tapanuli Selatan, Humbang Hasundutan, Padangsidempuan.

Komoditas lainnya seperti mangga, durian, dan pisang menjadi komoditas unggulan di banyak daerah kabupaten/kota di Provinsi Sumatera Utara. Komoditas mangga menjadi komoditas unggulan yang paling dominan di kabupaten/kota yang ada di Provinsi Sumatera Utara tetapi hasil penelitian yang dilakukan oleh Iyan (2014) bahwa komoditas mangga, durian dan pisang tidak menjadi komoditas unggulan di Provinsi Sumatera Utara. Hal ini disebabkan pada penelitiannya komoditas pertanian dibandingkan dengan komoditas pertanian di provinsi-provinsi lain yang ada di Pulau Sumatera, sehingga akan ketiga komoditas tersebut tidak lebih unggul dibandingkan dengan produksi di provinsi lain.

Komoditas-komoditas ini banyak daerah yang memproduksi karena komoditas ini biasanya tidak dibudidayakan secara khusus oleh petani. Seperti durian yang menjadi tumbuhan yang ada di sekitar rumah ataupun tanaman liar yang tumbuh di area hutan. Sedangkan komoditas jeruk memang dibudidayakan secara khusus oleh petani, seperti yang banyak dijumpai di daerah 
Kecamatan Berastagi dan lain-lain. Komoditas jeruk memang sangat dominan sekali menjadi komoditas unggulan di Provinsi Sumatera Utara di mana nilai LQ $=2,1631$ jika dibandingkan dengan provinsi lain di Pulau Sumatera (Iyan, 2014).

\section{Tabel 3.}

Hasil Analisis LQ Tanaman Buah-Buahan di Provinsi Sumatera Utara (Nilai LQ>1).

\begin{tabular}{lllll}
\hline Tanaman & Komoditas & Kabupaten/Kota & \\
\hline & Mangga & Mandailing Natal, Tapanuli Tengah, Tapanuli Utara, Toba
\end{tabular}

Samosir, Labuhan Batu, Asahan, Deli Serdang, Langkat, Nias

Selatan, Samosir, Serdang Bedagai, Batubara, Padang Lawas,

Labuhan Batu Selatan, Labuhan Batu Utara, Nias Barat, Tanjung

Balai, Pematang Siantar, Tebing Tinggi, Medan, Binjai,

Padangsidempuan, Gunungsitoli.

Durian Nias, Mandailing Natal, Tapanuli Tengah, Tapanuli Utara, Toba

Samosir, Labuhan Batu, Dairi, Nias Selatan, Pakpak Bharat,

Samosir, Serdang Bedagai, Pang Lawas, Labuhan Batu Selatan,

Labuhan Batu Utara, Nias Utara, Nias Barat, Pematang Siantar,

$\begin{array}{ll} & \text { Tebing Tinggi, Binjai, Gunungsitoli. } \\ \text { Buah-Buahan Jeruk } & \text { Tapanuli Utara, Dairi, Karo, Pakpak Bharat. }\end{array}$

Pisang Mandailing Natal, Toba Samosir, Deli Serdang, Langkat, Nias Selatan, Serdang Bedagai, Batubara, Padang Lawas, Labuhan Batu Utara, Nias Utara, Nias Barat, Tanjung Balai, Pematang Siantar, Tebing Tinggi, Binjai.

Pepaya Nias, Mandailing Natal, Toba Samosir, Labuhan Batu, Deli Serdang, Langkat, Nias Selatan, Samosir, Serdang Bedagai, Batubara, Padang Lawas, Labuhan Batu Selatan, Labuhan Batu Utara, Nias Barat, Tanjung Balai, Pematang Siantar, Tebing Tinggi, Medan, Binjai, Gunungsitoli.

Salak Tapanuli Selatan, Humbang Hasundutan, Padangsidempuan.

Sumber: Hasil Analisis $L Q$

\subsubsection{Tanaman Obat-obatan}

Jenis tanaman obat-obatan banyak sekali tetapi hanya komoditas jahe, lengkuas, kencur dan kunyit (BPS, 2019). Tanaman obat atau yang dikenal juga dengan tanaman biofarmaka dalam membudidayakannya tidak membutuhkan lahan yang luas seperti tanaman sayur dan buahbuahan. Tanaman obat tidak begitu familiar dibudidayakan oleh petani tetapi permintaan untuk tanaman ini terus meningkat.

Berdasarkan hasil analisis LQ pada Tabel 4. menunjukkan bahwa jahe menjadi komoditas unggulan di 6 kabupaten yaitu Kabupaten Tapanuli Selatan, Toba Samosir, Dairi, Karo, Pakpak Bharat dan Samosir. Sedangkan lengkuas, kencur dan kunyit menjadi komoditas unggulan di banyak daerah. Namun sedikit berbeda dengan hasil penelitian yang dilakukan oleh Bangun pada 2019 yang menyatakan jahe juga menjadi komoditas prioritas (R. H. Bangun, 2019). Hal ini disebabkan tahun data penelitian yang digunakan berbeda. Perbedaan hasil temuan penelitian yang dilakukan oleh Bangun (2019) bahwa tanaman biofarmaka yang menjadi komoditas unggulan di Provinsi Sumatera Utara yaitu jahe dan kunyit. Perbedaan disebabkan karena dalam penelitiannya komoditas yang dianalisis secara umum untuk Provinsi Sumatera Utara tidak spesifik per kabupaten/kota yang ada dan juga khusus meneliti komoditas unggulan untuk tanaman biofarmaka yang artinya produksi tanaman tersebut tidak dibandingkan dengan produksi dengan komoditas hortikultura lainnya. Akibatnya produksi jahe dan kunyit terlihat dominan jika dibandingkan dengan tanaman biofarmaka yang lainnya.

\subsubsection{Tanaman Bunga}

Tanaman bunga membutuhkan iklim dan cuaca yang khusus untuk bisa bertahan hidup. Biasanya bunga lebih bisa beradaptasi pada daerah yang beriklim dingin, seperti bunga krisan. Berdasarkan Tabel 5. terlihat tanaman bunga menjadi komoditas hortikultura unggulan lahan kering hanya di beberapa daerah kabupaten/kota saja. Tanaman anggrek menjadi komoditas unggulan di lebih banyak kabupaten/kota. Berdasarkan hasil penelitian yang dilakukan oleh Wihermanto \& Hartini (2013) jenis tanaman anggrek yang ada di Provinsi Sumatera Utara yaitu Paphiopedilum superbiens (Rchb.f.) Stein. Dibandingkan dengan tanaman sayuran dan buahbuahan tentu berbeda sekali. Selain masalah iklim dan cuaca, tanaman bunga tidak dibudidayakan oleh banyak petani karena butuh pengetahuan dan pemeliharan khusus. 
Permintaan tanaman bunga tidak sebanyak tanaman sayuran dan buah, karena bunga digunakan untuk acara-acara tertentu saja, bukan menjadi kebutuhan pokok seperti komoditas lainnya, sehingga ini menyebabkan petani jarang membudidayakan tanaman bunga.

Tabel 4.

Hasil Analisis LQ Tanaman Obat-Obatan di Provinsi Sumatera Utara (Nilai LQ>1).

\begin{tabular}{|c|c|c|}
\hline Tanaman & Komoditas & Kabupaten/Kota \\
\hline \multirow{5}{*}{ Obat-obatan } & Jahe & $\begin{array}{l}\text { Tapanuli Selatan, Toba Samosir, Dairi, Karo, Pakpak Bharat, } \\
\text { Samosir. }\end{array}$ \\
\hline & Lengkuas & Nias, Mandailing Natal, Tapanuli Selatan, Tapanuli Tengah, \\
\hline & & $\begin{array}{l}\text { Tapanuli Utara, Asahan, Dairi, Deli Serdang Langkat, } \\
\text { Humbang Hasundutan, Serdang Bedagai, Padang Lawas, } \\
\text { Nias Utara, Nias Barat, Tanjung Balai, Pematang Siantar, } \\
\text { Tebing Tinggi, Medan, Binjai, Padangsidempuan. }\end{array}$ \\
\hline & Kencur & $\begin{array}{l}\text { Tapanuli Selatan, Labuhan Batu, Asahan, Deli Serdang, } \\
\text { Langkat, Humbang Hasundutan, Pakpak Barat, Serdang } \\
\text { Bedagai, Padang Lawas, Tanjung Balai, Tebing Tinggi, } \\
\text { Medan, Padangsidempuan. }\end{array}$ \\
\hline & Kunyit & $\begin{array}{l}\text { Nias, Mandailing Natal, Simalungun, Langkat, Padang } \\
\text { Lawas, Nias Utara, Nias Barat, Pematang Siantar, } \\
\text { Gunungsitoli. }\end{array}$ \\
\hline
\end{tabular}

Sumber: Hasil Analisis $L Q$

Tabel 5.

Hasil Analisis LQ Tanaman Bunga di Provinsi Sumatera Utara (Nilai LQ $>1$ ).

\begin{tabular}{cllll}
\hline Tanaman & \multicolumn{1}{c}{ Komoditas } & \multicolumn{3}{c}{ Kabupaten/Kota } \\
\hline & Anggrek & $\begin{array}{l}\text { Tapanuli Selatan, Deli Serdang, Humbang Hasundutan, Tebing } \\
\text { Tinggi, Medan, Binjai, Padangsidempuan. }\end{array}$ \\
Bunga & Krisan & Karo. & \\
& Mawar & Tapanuli Tengah, Langkat, Pakpak Bharat, Medan, & Padangsidempuan, Gunungsitoli. \\
& Sedap Malam & Tapanuli Selatan, Medan, Padangsidempuan. & \\
\hline
\end{tabular}

Sumber: Hasil Analisis LQ

\subsection{Analisis Spesialisasi dan Lokalisasi Komoditas Hortikultura di Provinsi Sumatera Utara 4.2.1. Tanaman Sayuran}

Pada Gambar 1. sebelah kiri menunjukkan nilai spesialisasi dan lokalisasi (penyebaran) tanaman sayuran di setiap kabupaten/kota. Nilai spesialisasi menunjukkan apakah di suatu wilayah terdapat spesialisasi komoditas unggulan tertentu atau tidak dan nilai lokalisasi menunjukkan apakah di suatu wilayah terdapat penyebaran dari komoditas unggulan (Handayani et al., 2019). Dari gambar tersebut menunjukkan bahwa lebih dari 50 persen kabupaten/kota terspesialisasi komoditas cabai karena memiliki nilai SQ positif. Hal ini berarti lebih dari 50 persen kabupaten/kota di Provinsi Sumatera Utara memiliki keunggulan komparatif untuk komoditas cabai. Berbanding terbalik dengan komoditas bawang putih, semua daerah kabupaten/kota memiliki nilai SQ sama dengan 0 bahkan bernilai negatif. Kondisi ini menggambarkan bahwa bawang putih tidak memiliki keunggulan komparatif di kabupaten/kota yang ada di Provinsi Sumatera Utara. Kemudian komoditas bawang merah, kentang, kubis, petsai dan tomat hanya dibeberapa kebupaten/kota saja yang memiliki nilai SQ yang positif.

Nilai LoQ yang ditunjukkan pada Gambar 1. sebelah kanan menunjukkan tingkat penyebaran tanaman sayuran di setiap kabupaten/kota. Sebagian besar kabupaten/kota memiliki nilai LoQ mendekati nol dan negatif untuk setiap tanaman sayuran. Hal ini menunjukkan bahwa tanaman sayuran diproduksi atau ditanam secara merata di kabupaten/kota tersebut. Tetapi ada beberapa komoditas yang memiliki nilai LoQ yang positif yaitu bawang merah, kentang, kubis, petsai dan bawang putih.

Komoditas bawang merah memiliki nilai positif di Kabupaten Dairi, Humbang Hasundutan dan Samosir. Komoditas kentang memiliki nilai positif di Kabupaten Karo dan Samosir. Khusus jumlah penawaran komoditas kentang di Pronvinsi Sumatera Utara sangat dipengaruhi oleh harga dan luas panen (Sipayung \& Ginting, 2019). Artinya semakin tinggi harga dan luas panen maka jumlah penawaran kentang akan semakin banyak. Harga dan luas panen yang terus bertambah bisa meningkatkan nilai produksi kentang yang akan berpotensi mengakibatkan komoditas ini menjadi komoditas unggulan di beberapa daerah seperti Kabupaten Karo dan Samosir. Komoditas 
kubis memiliki nilai positif di Kabupaten Simalungun dan Karo. Komoditas Petsai hanya memiliki nilai positif di Kabupaten Karo saja. Komoditas bawang putih memiliki nilai positif di Kabupaten Tapanuli Utara, Humbang Hasundutan, Pakpak Bharat dan Samosir. Nilai LoQ yang positif ini menunjukkan bahwa komoditas tersebut diproduksi atau ditanam memusat di suatu wilayah di Kabupaten/Kota.

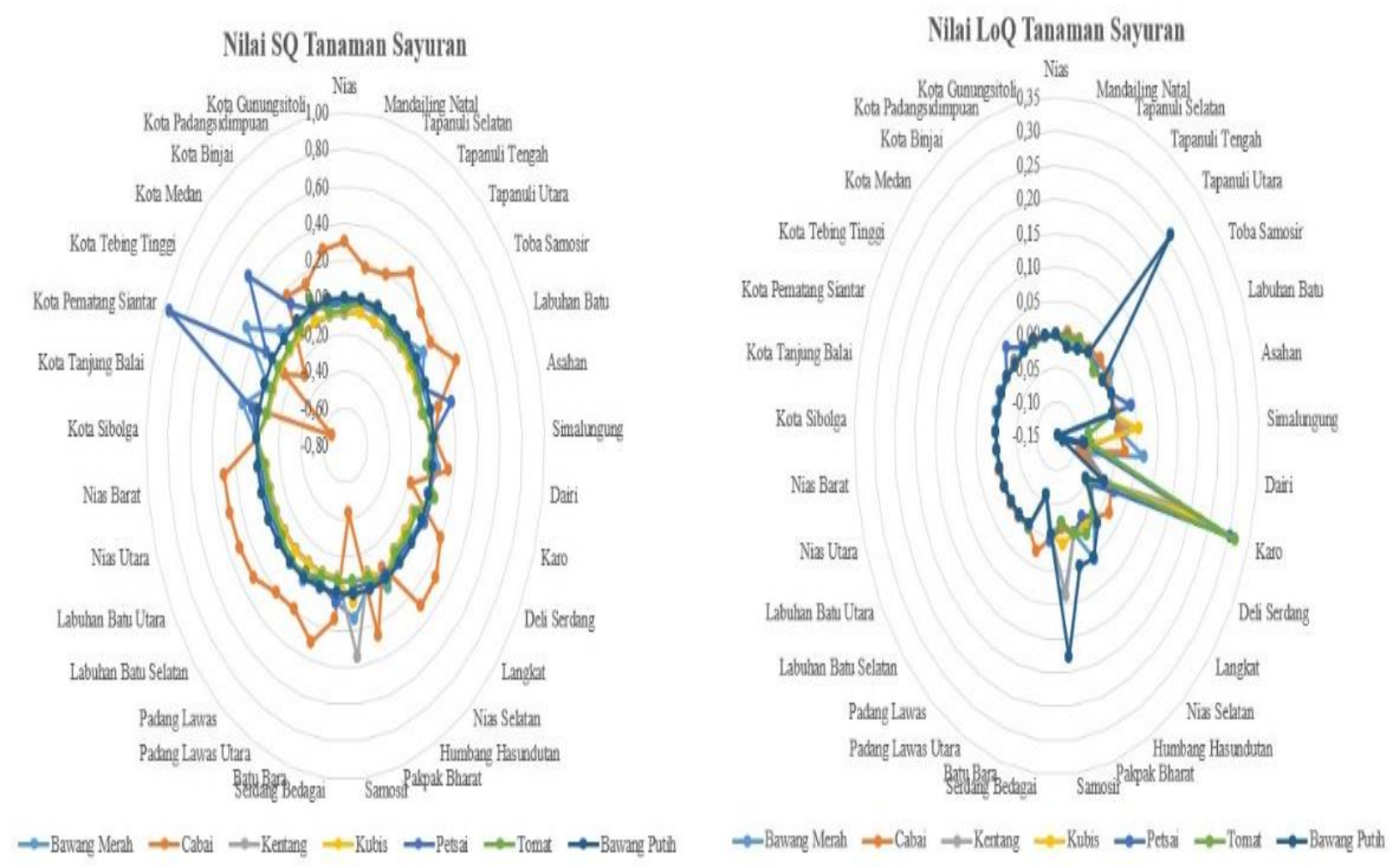

Gambar 1.

Nilai SQ dan LoQ Tanaman Sayuran Lahan Kering di Provinsi Sumatera Utara; Sumber: Hasil Analisis SQ dan LoQ (2020)

\subsubsection{Tanaman Buah-Buahan}

Tanaman buah-buahan memiliki keunggulan komparatif yang lebih merata di setiap daerah dibandingkan dengan komoditas sayuran. Hal ini ditunjukkan oleh nilai SQ bernilai positif di setiap kabupaten/kota (Gambar 2 kiri). Tanaman mangga dan pepaya menjadi komoditas yang memiliki keunggulan komparatif terbanyak di setiap daerah. Lebih dari 50 persen kabupaten/kota memiliki keunggulan komparatif untuk komoditas mangga dan pepaya. Durian menjadi komoditas yang memiliki kenggulan komparatif di Kabupaten Nias, Mandailing Natal, Dairi, Padang Lawas dan Nias Utara. Zulkarnain (2017) menyatakan bahwa banyak daerah di Provinsi Sumatera Utara yang menjadi sentra komoditas durian. Pisang menjadi komoditas yang memiliki keunggulan komparatif di Kabupaten Nias, Labuhan Batu Utara, Nias Utara, Nias Barat dan Tanjung Balai. Sedangkan salak hanya di Kabupaten Tapanuli Selatan, Humbang Hasundutan dan Padangsidempuang yang menjadi komoditas yang memiliki keunggulan komparatif.

Berdasarkan hasil analisis LoQ (Gambar 2 kanan) terhadap penyebaran produksi tanaman buah-buahan menunjukkan hal yang berbeda dengan analisis SQ. Pada hasil SQ menunjukkan hampir semua daerah memiliki keunggulan komparatif untuk komoditas mangga, tetapi dari hasil analisis LoQ nilai komoditas mangga di semua daerah sama dengan 0 bahkan bernilai negatif. Hal ini berarti bahwa 50 persen daerah yang memiliki keunggulan komparatif untuk komoditas mangga, produksi mangganya tersebar secara merata di wilayah kabupaten/kota tersebut. Hal ini juga didukung dari hasil penelitian Hendayana (2003) bahwa luas lahan produksi mangga di Provinsi Sumatera Utara tidak lebih tinggi dibandingkan luas lahan produksi mangga di provinsi lain yang ada di Indonesia. Produksi durian terpusat untuk Kabupaten Tapanuli Tengah dan Tapanuli Utara karena memiliki nilai LoQ positif, sedangkan salak hanya di Kabupaten Tapanuli Selatan yang diproduksi atau ditanam terpusat di suatu wilayah. 

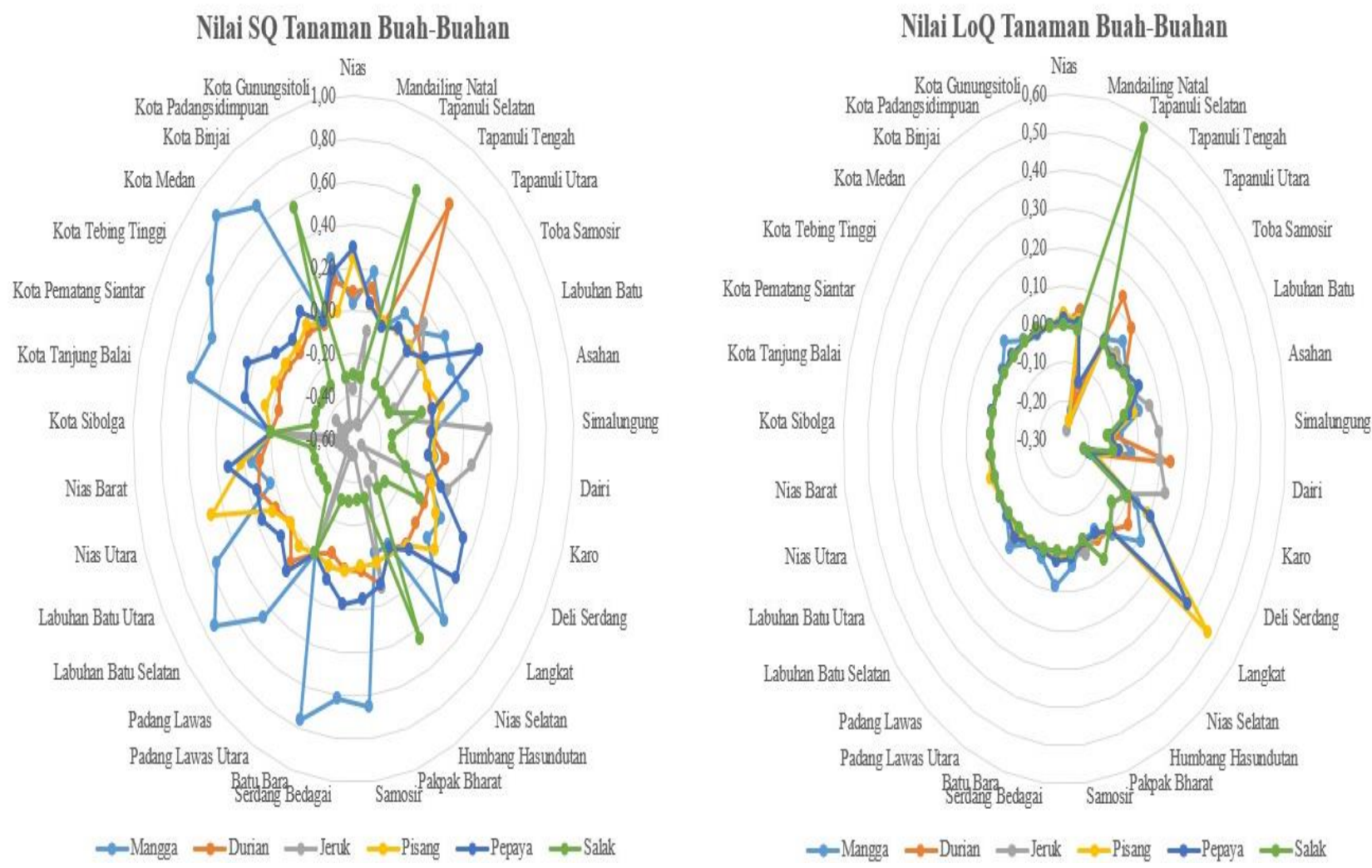

Gambar 2.

Nilai SQ dan LoQ Tanaman Buah-Buahan Lahan Kering di Provinsi Sumatera Utara; Sumber: Data Sekunder Diolah (2020)

\subsubsection{Tanaman Obat-Obatan}

Tanaman obat-obatan yang dianalisis yaitu jahe, lengkuas, kencur dan kunyit. Dari hasil analisis SQ terhadap keempat komoditas tersebut menunjukkan bahwa hampir 50 persen memiliki nilai SQ yang positif (Gambar 3 kiri). Berdasarkan hasil analisis 50 persen kabupaten/kota di Provinsi Sumatera Utara memiliki keunggulan komparatif untuk komoditas jahe. Kunyit dan kencur hanya di beberapa kabupaten/kota yang memiliki nilai SQ yang positif tetapi jahe hanya di 5 daerah saja yang memiliki nilai SQ yang positif yaitu Kabupaten Toba Samosir, Dairi, Karo, Pakpak Bharat dan Samosir. Artinya komoditas jahe memiliki keunggulan komparatif di 5 kabupaten tersebut. Jahe merupakan komoditas unggulan yang berkontribusi besar terhadap total produksi tanaman obat-obatan di Provinsi Sumatera Utara (R. H. B. Bangun, 2021).

Nilai LoQ yang mencermikan penyebaran tanaman obat-obatan pada Gambar 3 sebelah kanan menunjukkan bahwa sebagian besar tanaman obat-obatan diproduksi atau ditanam secara merata di wilayah kabupaten/kota karena nilai LoQ sama dengan nol atau benilai negatif. Komoditas yang nilai LoQ yang positif yaitu jahe, lengkuas dan kencur. Komoditas jahe produksinya terpusat hanya di Kabupaten Toba Samosir, komoditas lengkuas terpusat produksinya di Kabupaten Tapanuli Utara dan Deli Serdang. Sedangkan komoditas kencur produksinya terpusat di Kabupaten Tapanuli Utara.

\subsubsection{Tanaman Bunga}

Berdasarkan hasil analisis SQ terhadap tanaman bunga pada Gambar 4. sebelah kiri menunjukkan tidak ada satupun kabupaten/kota yang memiliki keunggulan komparatif untuk komoditas krisan. Sedangkan untuk anggrek ada 8 daerah, mawar ada 4 daerah dan sedap malam hanya 1 daerah yang memiliki keunggulan komparatif karena memiliki nilai SQ positif. Delapan daerah kabupaten/kota yang memiliki keunggulan komparatif untuk komoditas anggrek yaitu Tapanuli Selatan, Asahan, Deli Serdang, Humbang Hasundutan, Tebing Tinggi, Medan, Binjai dan Padang Sidempuan. Ada empat daerah yang memiliki keunggulan komparatif untuk komoditas mawar yaitu Tapanuli Selatan, Tebing Tinggi, Binjai, dan Padangsidempuan. Sedangkan untuk Sedap malam hanya di Kota Medan yang menjadi keunggulan komparatif.

Penyebaran produksi komoditas berdasarkan nilai LoQ yang bisa dilihat pada Gambar 4. sebelah kanan, komoditas krisan, mawar, dan sedap malam diproduksi secara merata di wilayah kabupaten/kota. Sumatera Utara merupakan penyumbang produksi tanaman bunga sedap malam sebanyak 1,26 persen atau 1,31 juta tangkai secara nasional (Tinaprilla \& Pratiwi, 2017). 

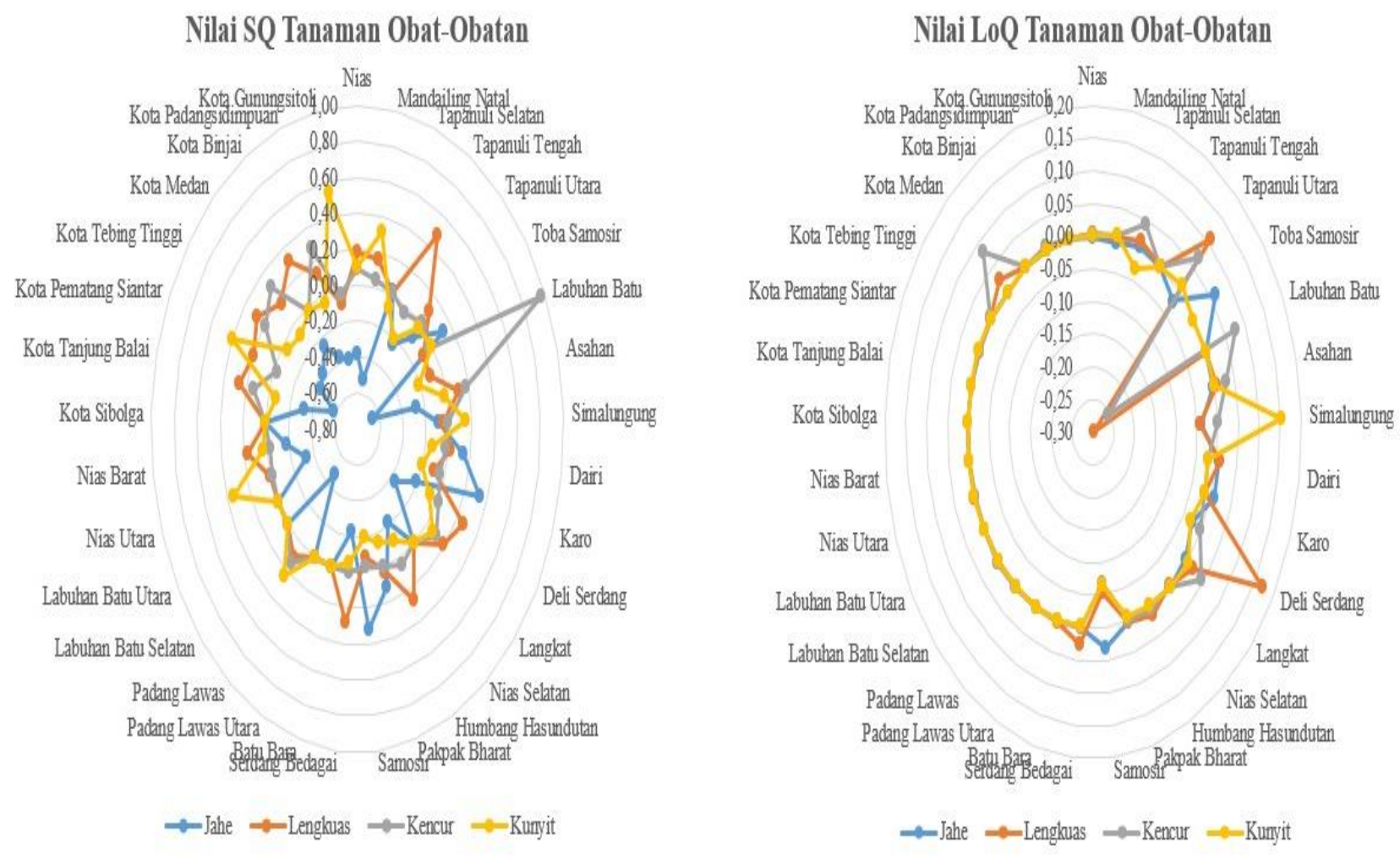

Gambar 3.

Nilai SQ dan LoQ Tanaman Obat-Obatan Lahan Kering di Provinsi Sumatera Utara; Sumber: Data Sekunder Diolah (2020)
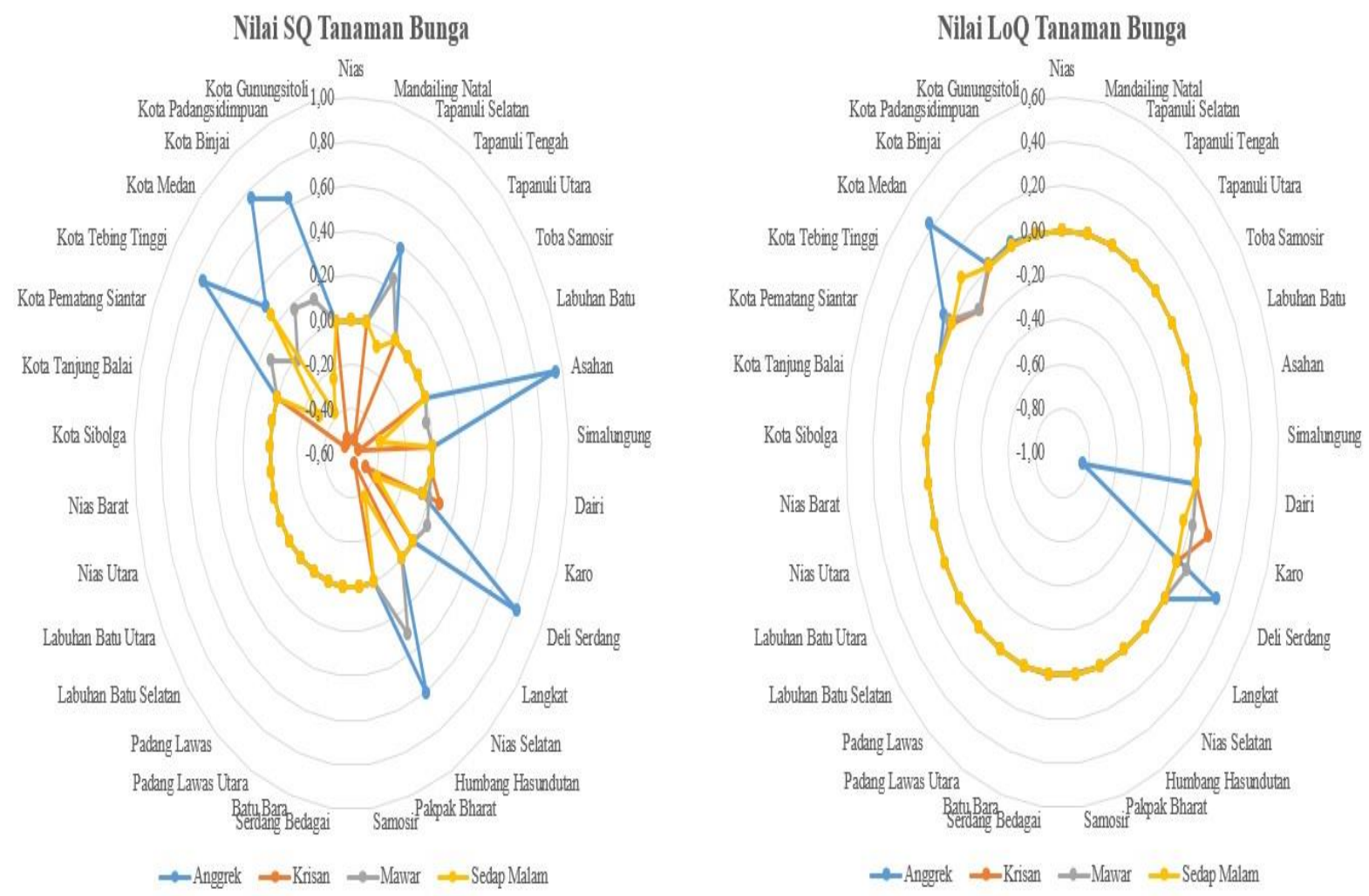

Gambar 4.

Nilai SQ dan LoQ Tanaman Bunga Lahan Kering di Provinsi Sumatera Utara; Sumber: Data Sekunder Diolah (2020)

\subsection{Analisis Komoditas Hortikultura Prioritas Lahan Kering di Provinsi Sumatera Utara}

Analisis komoditas hortikultura lahan kering prioritas ditentukan berdasarkan nilai LQ > 1 dan SQ > 0. Berdasarkan kombinasi nilai LQ dan SQ tersebut ditemui kabupaten/kota yang memiliki 2 komoditas prioritas untuk 1 kriteria tanaman dan ada yang tidak memiliki komoditas 
prioritas di salah satu kriteria tanaman. Hal ini bisa disebabkan karena komoditas hortikultura juga membutuhkan adaptasi terhadap perubahan iklim yang ada di wilayah tersebut. Usaha yang bisa dilakukan untuk komoditas hortikultura terhadap perubahan iklim di suatu wilayah yaitu menggunakan varietas unggul, menggunakan irigasi, benih berkualitas, pengendalian hama dan penggunaan mulsa (Hilman, Suciantini, \& Rosliani, 2019). Dari hasil analisis yang dilakukan dapat dilihat pada Tabel 6 . bahwa:

a. Tanaman Sayuran: Ada 23 kabupaten/kota yang menjadi prioritas untuk komoditas cabai, 6 kabupaten/kota menjadi prioritas untuk komoditas bawang merah, 5 kabupaten/kota menjadi prioritas untuk komoditas petsai, dan masing-masing 1 kabupaten/kota menjadi prioritas untuk komoditas kentang, kubis dan tomat.

b. Tanaman Buah-Buahan: Ada 21 kabupaten/kota yang menjadi prioritas untuk komoditas mangga, 5 kabupaten/kota menjadi prioritas untuk komoditas durian, 3 kabupaten/kota menjadi prioritas untuk komoditas jeruk, dan 1 kabupaten menjadi prioritas untuk komoditas pisang.

c. Tanaman Obat-Obatan: Ada 16 kabupaten/kota yang menjadi prioritas untuk komoditas lengkuas, 7 kabupaten/kota menjadi prioritas untuk komoditas kencur, dan 5 kabupaten menjadi prioritas untuk komoditas jahe.

d. Tanaman Bunga: Ada 7 kabupaten/kota yang menjadi prioritas untuk komododiti anggrek, dan masing-masing 1 kabupaten/kota yang menjadi prioritas untuk komoditas mawar dan sedap malam.

Pada Tabel 6. di atas jika dianalisis berdasarkan lokasi atau kabupaten/kota yang lebih spesifik seperti Kabupaten Deli Serdang yang menjadi prioritas komoditas hortikultura lahan kering khususnya untuk tanaman yang semusim. Hal ini sesuai dengan penelitian yang dilakukan oleh (Sari \& Herawaty, 2019) bahwa subsektor tanaman hortikultura semusim memiliki keunggulan komparatif, tetapi pada penelitian tersebut belum menjelaskan secara spesifik apa komoditasnya, jadi pada penelitian ini bisa terlihat bahwa komoditasnya adalah seperti cabai, lengkuas dan anggrek. Kabupaten Simalungun diprioritaskan untuk mengembangkan komoditas jeruk sesuai dengan Tabel 6. Hasil berbeda yang ditemukan oleh penelitian (Saragih et al., 2021) bahwa komoditas hortikultura unggulan lahan kering yaitu bawang merah. Terjadi perbedaan hasil penelitian ini disebabkan peneliti tersebut menganalisis komoditas unggulan pertanian secara umum seperti tanaman pangan, perkebunan dan peternakan sehingga hasil penelitian juga akan berbeda.

Hasil analisis komoditas hortikultura prioritas yang dilakukan pada penelitian ini jika dibandingkan dengan rencana kebijakan komoditas hortikultura Provinsi Sumatera Utara yang akan dilakukan oleh pemerintah akan terlihat beberapa persamaan dan perbedaan komoditas hortikultura lahan kering yang diprioritaskan untuk dikembangkan (lihat Tabel 7). Persamaan dan perbedaan terjadi di 4 tanaman hortikulra yaitu:

a. Tanaman sayuran: Ada 2 komoditas yang hasilnya sama yaitu bawang merah dan cabai. Dari hasil analisis komoditas kubis, tomat dan petsai juga menjadi komoditas prioritas tetapi dalam rencana kebijakan pemerintah komoditas tersebut tidak dimasukan dalam rencana pengembangan komoditas hortikutura di Provinsi Sumatera Utara. Pemerintah melihat bawang putih, kentang, jamur dan sayuran daun menjadi komoditas yang diprioritaskan untuk dikembangkan.

b. Tanaman buah-Buahan: Komoditas jeruk dan pisang sama-sama diprioritaskan baik dari hasil analisis dan rencana kebijakan pemerintah. Tetapi mangga dan durian tidak menjadi prioritas dalam rencana kebijakan pemerintah. Pemerintah lebih memilih nanas untuk dikembangkan.

c. Tanaman Obat-obatan: Tanaman obat dalam dokumen pemerintah tidak dijelaskan secara spesifik apa komoditasnya tetapi pemerintah memasukan komoditas obat-obatan untuk dikembangkan di Provinsi Sumatera Utara. Berdasarkan hasil penelitian tanaman obat yang bisa dikembangkan yaitu lengkuas, kencur dan jahe, sehingga ini bisa menjadi rekomendasi untuk pemerintah dalam pemilihan komoditas obat-obatan untuk dikembangkan di Provinsi Sumatera Utara.

Tanaman Bunga: Mawar dan sedap malam tidak masuk dalam rencana kebijakan pemerintah, tetapi anggrek berdasarkan hasil penelitian dan rencana pemerintah juga menjadi tanaman bunga yang diprioritaskan untuk dikembangkan.

\section{Tabel 6.}

Hasil Analisis LQ dan SQ Komoditas Hortikultura di Provinsi Sumatera Utara (Nilai LQ > 1 dan SQ $>0)$.

No.

Kabupaten

Tanaman 


\begin{tabular}{|c|c|c|c|c|}
\hline & Sayuran & Buah-Buahan & Obat-Obatan & Bunga \\
\hline 1 Nias & Cabai & Durian, Pisang & Lengkuas, Kencur & - \\
\hline 2 Mandailing Natal & Cabai & Mangga, Durian & Lengkuas & - \\
\hline 3 Tapanuli Selatan & Cabai & - & - & Anggrek \\
\hline 4 Tapanuli Tengah & Cabai & Mangga, Durian & Lengkuas & - \\
\hline 5 Tapanuli Utara & - & Jeruk & Lengkuas & - \\
\hline 6 Toba Samosir & $\begin{array}{l}\text { Bawang Merah, } \\
\text { Cabai }\end{array}$ & Mangga & Jahe, Kencur & - \\
\hline 7 Labuhan Batu & Cabai & Mangga & Kencur & - \\
\hline 8 Asahan & Cabai, Petsai & Mangga & Lengkuas, Kencur & - \\
\hline 9 Simalungung & - & Jeruk & - & - \\
\hline 10 Dairi & $\begin{array}{l}\text { Bawang Merah, } \\
\text { Cabai }\end{array}$ & Durian, Jeruk & Jahe & - \\
\hline 11 Karo & $\begin{array}{l}\text { Kentang, Kubis, } \\
\text { Tomat }\end{array}$ & Jeruk & Jahe & - \\
\hline 12 Deli Serdang & Cabai & Mangga & Lengkuas & Anggrek \\
\hline 13 Langkat & Cabai & Mangga & Lengkuas, Kencur & - \\
\hline 14 Nias Selatan & Cabai & Mangga & & - \\
\hline 15 Humbang Hasundutan & Bawang Merah & - & Lengkuas & Anggrek \\
\hline 16 Pakpak Bharat & Cabai & - & Jahe & - \\
\hline 17 Samosir & $\begin{array}{l}\text { Bawang Merah, } \\
\text { Kubis }\end{array}$ & Mangga & Jahe & - \\
\hline 18 Serdang Bedagai & Cabai, Petsai & Mangga & Lengkuas & - \\
\hline 19 Batu Bara & Cabai & Mangga & - & - \\
\hline 20 Padang Lawas Utara & Cabai & - & - & - \\
\hline 21 Padang Lawas & Cabai & Mangga, Durian & Lengkuas, Kencur & - \\
\hline 22 Labuhan Batu Selatan & Cabai & Mangga & - & - \\
\hline 23 Labuhan Batu Utara & Cabai & Mangga & - & - \\
\hline 24 Nias Utara & Cabai & Durian & - & - \\
\hline 25 Nias Barat & Cabai & Mangga & - & - \\
\hline 26 Kota Sibolga* & $\mathrm{N} / \mathrm{A}$ & $\mathrm{N} / \mathrm{A}$ & $\mathrm{N} / \mathrm{A}$ & $\mathrm{N} / \mathrm{A}$ \\
\hline 27 Kota Tanjung Balai & - & Mangga & Lengkuas & - \\
\hline 28 Kota Pematang Siantar & Petsai & Mangga & Lengkuas & - \\
\hline 29 Kota Tebing Tinggi & Bawang Merah & Mangga & Lengkuas, Kencur & Anggrek \\
\hline 30 Kota Medan & Bawang Merah & Mangga & Lengkuas, Kencur & $\begin{array}{l}\text { Anggrek, Sedap } \\
\text { Malam }\end{array}$ \\
\hline 31 Kota Binjai & Cabai, Petsai & Mangga & Lengkuas & Anggrek \\
\hline 32 Kota Padangsidimpuan & Cabai, Petsai & - & Lengkuas & $\begin{array}{l}\text { Anggrek, } \\
\text { Mawar }\end{array}$ \\
\hline 33 Kota Gunungsitoli & Cabai & Mangga & - & - \\
\hline
\end{tabular}

Sumber: Data Sekunder Data Diolah (2020)

*Data tidak tersedia

Tabel 7.

Perbandingan Komoditas Hortikultura Prioritas Hasil Analisis dan Rencana Pemerintah.

\begin{tabular}{clll}
\hline No & Tanaman & Hasil Penelitian & Rencana Kebijakan Pemerintah \\
\hline 1 & Sayuran & Bawang Merah & Bawang Merah \\
& & Cabai & Cabai \\
& & Kubis & Bawang Putih \\
& Tomat & Kentang \\
& & Petsai & Jamur \\
& & Sayuran Daun \\
2 & Buah-Buahan & Jeruk & Jeruk \\
& & Pisang & Pisang \\
& & Mangga & Nanas \\
3 & Obat-obatan & Lurian & Tanaman Obat \\
& & Kencur & \\
& & Jahe & Krisan \\
& Bunga & Mawar & Anggrek \\
& & Sedap Malam &
\end{tabular}

Sumber: Hasil Analisis dan (Hortikultura, 2020)

\section{SIMPULAN}

Berdasarkan hasl penelitian ini menunjukkan bahwa (1) komoditas hortikultura unggulan lahan kering di Provinsi Sumatera Utara didominasi oleh bawang merah, cabai, mangga, durian, papaya, dan lengkuas di Kabupaten Tapanuli Utara, Toba Samosir, dan Dairi, (2) beberapa 
komoditas hortikultura lahan kering di Provinsi Sumatera Utara memiliki keunggulan komparatif dan produksinya tidak terlokalisasi seperti komoditas mangga, durian, petsai dan cabai di Kabupaten Batu Bara dan Labuhan Batu Selatan dan (3) lima puluh persen komoditas hortikultura prioritas lahan kering. Sehingga pemerintah perlu mengakomodir beberapa komoditas hortikultura lahan kering yang sebenarnya potensial untuk dikembangkan untuk menggerakan perekonomian daerah.

\section{Ucapan Terima Kasih}

Terimakasih kepada Direktorat Riset dan Pengabdian kepada Masyarakat (DRPM) Kemenristekdikti melalui Lembaga Penelitian dan Pengabdian kepada Masyarakat (LPPM) Politeknik Wilmar Bisnis Indonesia yang telah mendanai penelitian ini dan kepada rekan-rekan dosen program studi Agribisnis Hortikultura yang telah turut berkontribusi dalam penelitian ini.

\section{Pustaka}

Antara, M. (2005). Pengembangan Usaha Hortikultura Petani Kecil. SOCA: Socioeconomics of Agriculture and Agribusiness, 5(2), 30-31.

Bangun, R. H. (2019). Identifikasi Komoditas Unggulan Untuk Peningkatan Daya Saing Biofarmaka Di Sumatera Utara. Jurnal Agrica, 12(1), 25. https://doi.org/10.31289/agrica.v12i1.2219

Bangun, R. H. B. (2021). Karakteristik Petani dan Kelayakan Usahatani Jahe di Sumatera Utara. J. Agribisnis. Komun. Pertan, 4(April), 1-8.

BPS. (2018). Konsumsi Kalori dan Protein Penduduk Indonesia dan Provinsi. Jakarta.

BPS. (2019). Provinsi Sumatera Utara Dalam Angka 2019. Sumatera Utara.

Crawley, A., Beynon, M., \& Munday, M. (2013). Making Location Quotients More Relevant as a Policy Aid in Regional Spatial Analysis. Urban Studies, 50(9), 1854-1869. https://doi.org/10.1177/0042098012466601

Fimbriata, F. A., Budiraharjo, K., \& Mukson. (2020). Analisis Potensi Pengambangan Kubis Organik pada Kelompok Tani Bankit Merbabu Kecamatan Getasan Kabupaten Semarang. Jurnal Ekonomi Pertanian Dan Agribisnis (JEPA), 4, 258-267.

Habib, A. (2019). Analisis Komoditi Unggulan Tanaman Pangan dan Hortikultura di Sumatera Utara dan Penerapan Konsep One Village One Product (OVOP). (August).

Handayani, E., Shaleh, K. S., \& Panggabean, E. L. (2019). Identifikasi Potensi Komoditas Unggulan Sektor Pertanian Tanaman Pangan Pada Kecamatan di Kabupaten Deli Serdang Provinsi Sumatera Utara. Jurnal Ilmiah Pertanian (JIPERTA), 1(2), 163-174.

Hendayana, R. (2003). Aplikasi Metode Location Quotient (LQ) dalam Penentuan Komoditas Unggulan Nasional. Jurnal Informatika Pertanian, 12(Desember 2003), 1-21. Retrieved from http://www.litbang.pertanian.go.id/warta-ip/pdf-file/rahmadi-12.pdf

Hilman, Y., Suciantini, S., \& Rosliani, R. (2019). Adaptasi Tanaman Horikultura Terhadap Perubahan Iklim Lahan Kering. Jurnal Penelitian Dan Pengembangan Pertanian, 38(1), 55. https://doi.org/10.21082/jp3.v38n1.2019.p55-64

Hortikultura, D. J. (2020). Kebijakan Dan Program Pembangunan Hortikultura 2020.

Irawan, B. (2003). Agribisnis hortikultura: peluang dan tantangan dalam era perdagangan bebas. 122.

Iyan, R. (2014). ANalisis Komoditas Unggulan Sektor Pertanian di Wilayah Sumatera. (11), 215-235.

Kementan. (2018). Statistik Pertanian 2018.

Lestari, D. P., Widyayanthi, L., \& Kuntadi, E. B. (2014). Tingkat Motivasi dan Strategi Pengembangan Usahatani Cabai Merah Besar di Jember. Agritrop Jurnal Ilmu-Ilmu Pertanian, $12,159-167$.

Nuhung, I. A. (2013). Strategi Pengendalian Impor Hortikultura. Agribusiness Journal, 7(2), 173188. https://doi.org/10.15408/aj.v7i2.5177

Ropingi. (2006). Pembangunan wilayah kecamatan berbasis komoditas pertanian di kabupaten gunungkidul propinsi daerah istimewa yogyakarta.

Santosa, E. P., Firdaus, M., \& Novianti, T. (2018). Dayasaing Komoditas Hortikultura Negara Berkembang Dan Negara Maju Di Pasar Internasional. Jurnal Ekonomi Dan Kebijakan Pembangunan, 5(2), 68-86. https://doi.org/10.29244/jekp.5.2.68-86

Saragih, J. R., Siburian, A., Harmain, U., \& Purba, T. (2021). Komoditas Unggulan dan Potensial Sektor Pertanian Kabupaten Simalungun, Komoditas Unggulan dan Potensial Sektor Pertanian Kabupaten Simalungun, Provinsi Sumatera Utara The Leading and Potential Commodity of Agriculture Sector in Simalungun Regency , Nor. (March). https://doi.org/10.37637/ab.v4i1.633

Sari, F. W. A. W., \& Herawaty, B. R. (2019). Analisis Peranan Sektor Pertanian, Kehutanan dan Perikanan pada Perekonomian Kabupaten Deli Serdang. Journal Agroland, 26(3), 198-211. 
Silvia, H., Syamsun, M., \& Kartika, L. (2015). Strategy Analysis for Increasing Competitiveness of Potato Commodity in Karo Regency, North Sumatera. Jurnal Imu Pertanian Indonesia, 20(2), 164-170. https://doi.org/10.18343/jipi.20.2.164

Sipayung, B. P., \& Ginting, R. (2019). Analisis Faktor Penawaran Kentang di Provinsi Sumatera Utara (Periode 2003-2012). Agrimor, 4(1), 7-8. https://doi.org/ 10.32938/ag.v4i1.692

Sjafrizal. (2008). Ekonomi Regional: Teori dan Aplikasi. Padang: Baduose Media.

Tinaprilla, N., \& Pratiwi, C. P. (2017). Potensi Agribisnis Florikultura di Indonesia. Menuju Agribisnis Indonesia Yang Berdaya Saing, 106. Retrieved from http://agribisnis.ipb.ac.id/wpcontent/uploads / 2017/11/07-Netti-n-Rani.pdf

Vaulina, S. K. (2016). Identifikasi Komoditi Unggulan Pada Sektor Pertanian di Kabupaten Indragiri Hilir Provinsi Riau. Jurnal Agribinsis, 18(1), 42-54. Retrieved from https://journal.unilak.ac.id/index.php/agr/article/view/755/541

Wihermanto, \& Hartini, S. (2013). Keragaman Jenis Anggrek Tanah di Sumatra yang Mempunyai Daun Indah. Ekologia, 13(1), 1-8.

Zulkarnain. (2017). Budidaya Buah-Buahan Tropis. Yogyakarta: Deepublish. 